\title{
Effect of Silver Nanoparticle Size on Efficiency Enhancement of Dye-Sensitized Solar Cells
}

\author{
Chanu Photiphitak, ${ }^{1}$ Pattana Rakkwamsuk, ${ }^{1}$ Pennapa Muthitamongkol, ${ }^{2}$ \\ Chaiyuth Sae-Kung, ${ }^{3}$ and Chanchana Thanachayanont ${ }^{2}$ \\ ${ }^{1}$ School of Energy, Environment and Materials, Division of Materials Technology, King Mongkut's University of Technology Thonburi, \\ 126, Pracha-utid Road, Bangmod, Toongkru, Bangkok 10150, Thailand \\ ${ }^{2}$ National Metal and Material Technology Center, 114 Thailand Science Park, Phaholyothin Road, Klong 1, Klong Luang, \\ Pathumthani 12120, Thailand \\ ${ }^{3}$ Institute of Solar Energy Technology Development, Phaholyothin Road, Pathumthani 12120, Thailand
}

Correspondence should be addressed to Chanchana Thanachayanont, chanchm@mtec.or.th

Received 13 December 2010; Revised 12 April 2011; Accepted 25 April 2011

Academic Editor: Vincenzo Augugliaro

Copyright (c) 2011 Chanu Photiphitak et al. This is an open access article distributed under the Creative Commons Attribution License, which permits unrestricted use, distribution, and reproduction in any medium, provided the original work is properly cited.

Titanium dioxide/silver $\left(\mathrm{TiO}_{2} / \mathrm{Ag}\right)$ composite films were prepared by incorporating $\mathrm{Ag}$ in pores of mesoporous $\mathrm{TiO}_{2}$ films using a photoreduction method. The Ag nanoparticle sizes were in a range of $4.36-38.56 \mathrm{~nm}$. The $\mathrm{TiO}_{2} / \mathrm{Ag}$ composite films were characterized by X-ray diffraction (XRD), scanning electron microscopy (SEM) and transmission electron microscopy (TEM). The $\mathrm{TiO}_{2}$ and $\mathrm{TiO}_{2} / \mathrm{Ag}$ composite films were then sensitized by immersing in a $0.3 \mathrm{mM}$ N719 dye solution and fabricated for conventional dye-sensitized solar cells (DSCs). $J-V$ characteristics of the $\mathrm{TiO}_{2} / \mathrm{Ag}$ DSCs showed that the Ag nanoparticle size of $19.16 \mathrm{~nm}$ resulted in the short circuit current density and efficiency of $8.12 \mathrm{~mA} / \mathrm{cm}^{2}$ and $4.76 \%$.

\section{Introduction}

Surface plasmon resonance induced by silver (Ag) nanoparticles leads to an increase in an absorption coefficient of dye in dye-sensitized solar cells (DSCs) [1-6]. The effect has been theoretically described as an increase of local electromagnetic field nearby metal surfaces which is found when wavelengths of irradiation sources are correlated with the optical absorption of the surface plasmon resonance [711]. The modification of the surfaces for an enhancement of optical absorption, hence, provides a good method to improve efficiency of an optoelectronic device involving photon absorption [12]. Several methods for the fabrication of the silver nanoparticles were studied such as thermal evaporation of $\mathrm{Ag}$ islands on titanium dioxide $\left(\mathrm{TiO}_{2}\right)$ films [1], magnetron sputtering of $\mathrm{TiO}_{2}$ and $\mathrm{Ag}$ composite films [13], electrochemical deposition of $\mathrm{Ag}$ by double pulse method on indium tin oxide (ITO) [14], loading of Ag and silver chloride $(\mathrm{AgCl})$ onto anatase $\mathrm{TiO}_{2}$ nanotubes that were grown by a hydrothermal treatment [15] and loading of the Ag nanoparticles onto self-organized $\mathrm{TiO}_{2}$ nanotube layers using photocatalytic reduction $[16,17]$.

Wen et al. [1] generated the Ag island films by depositing the 3.3-6.0 nm-thick Ag nanoparticle layer on the $\mathrm{TiO}_{2}$ film electrode using thermal evaporation and found a possibility of using plasmon resonance effect to enhance the efficiency of the DSCs, if the volume and structure of the Ag island films could be controlled and optimized. Ihara et al. [18] improved photoelectric conversion efficiency of their dyesensitized solar cells by using localized surface plasmon of the Ag nanoparticles (diameter of $12.5 \mathrm{~nm}$ ) modified with polymer and reported that the efficiency of dye-sensitized solar cell with the Ag nanoparticles increased from 1.5\% to $2.5 \%$ compared with the case with no Ag nanoparticles. Chen et al. [19] studied effects of adding silver nanowires ( $40 \mathrm{~nm}$ in diameter and $20 \mu \mathrm{m}$ in length) in the anode of the DSCs to improve the photovoltaic efficiency. Results showed that the composite anode of $\mathrm{Ag}$ nanowires and $\mathrm{TiO}_{2} / \mathrm{P} 25$ has 


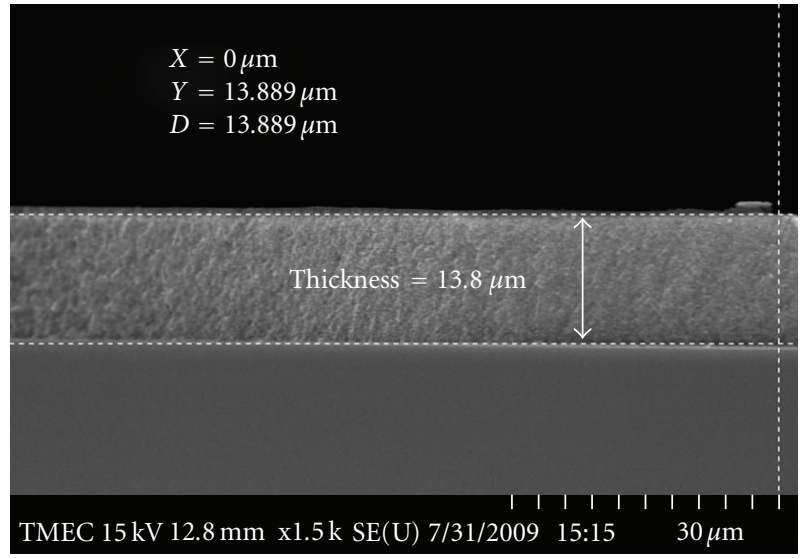

Figure 1: An SEM image showing a cross-section of the $\mathrm{TiO}_{2}$ film.

improved photovoltaic conversion efficiency about two times of standard P-25 DSCs. Chou et al. [20] prepared $\mathrm{TiO}_{2} / \mathrm{Ag}$ composite particles by dry particle-coating technique. The $\mathrm{Ag}$ particle size was bigger than $100 \mathrm{~nm}$, and the $\mathrm{TiO}_{2} / \mathrm{Ag}$ composite particles were found to improve the efficiency of the DSCs because Schottky barrier exceeded that of the conventional DSCs.

In this study, for a cost-effective process, we prepared the Ag nanoparticles with sizes in a range of $4.36-38.56 \mathrm{~nm}$ using a photoreduction method. The Ag nanoparticles were deposited onto the mesoporous anatase $\mathrm{TiO}_{2}$ electrode with worm-like pores. The Ag nanoparticles were incorporated thoroughly into the pores of the mesoporous $\mathrm{TiO}_{2}$ film electrode [21-24]. The effect of the Ag nanoparticle size on the efficiency enhancement of dye-sensitized solar cells was investigated. The optimum DSC in this study showed a maximum efficiency of $4.76 \%$. Although the $5.45 \%$ efficiency by using a similar material $\left(\mathrm{TiO}_{2} / \mathrm{Ag} / \mathrm{DSC}\right)$ has been showed in 2007 by Ramasamy et al. [25], this is the first time that the effect of Ag particle sizes is carefully investigated.

\section{Materials and Methods}

2.1. The Preparation of Mesoporous $\mathrm{TiO}_{2}$ Electrodes. The $\mathrm{TiO}_{2}$ electrodes were screen printed from a $\mathrm{TiO}_{2}$ paste (Dyesol) 3 times on a fluorine-doped tin oxide (FTO) glass substrate $\left(2 \times 3 \mathrm{~cm}^{2}\right.$ in size). A 200 mesh was used to obtain a $\mathrm{TiO}_{2}$ layer with area of $0.5 \times 1.2 \mathrm{~cm}^{2}$ and a thickness of approximately $13.8 \mu \mathrm{m}$ (see Figure 1). In order to avoid contamination on the fresh film, screen printing was performed in a clean-room environment. After drying at $55^{\circ} \mathrm{C}$ for 30 minutes, the electrodes were sintered at $450^{\circ} \mathrm{C}$ for 30 minutes, and then cooled down to room temperature. The electrodes were immersed in a $3 \times 10^{-4} \mathrm{M}$ of N719 dye solution, namely, cis-diisothiocyanato-bis(2,2-bipyridyl-4,4dicarboxylatoe) ruthenium (II)bis (tetrabutylammonium) in absolute ethanol for 24 hours. The excess dye was removed from the electrode by rinsing with ethanol.

2.2. The Synthesis of Mesoporous $\mathrm{TiO}_{2} / \mathrm{Ag}$ Films. In order to deposit the $\mathrm{Ag}$ nanoparticles on the $\mathrm{TiO}_{2}$ film, a $2 \times 3 \mathrm{~cm}^{2}$
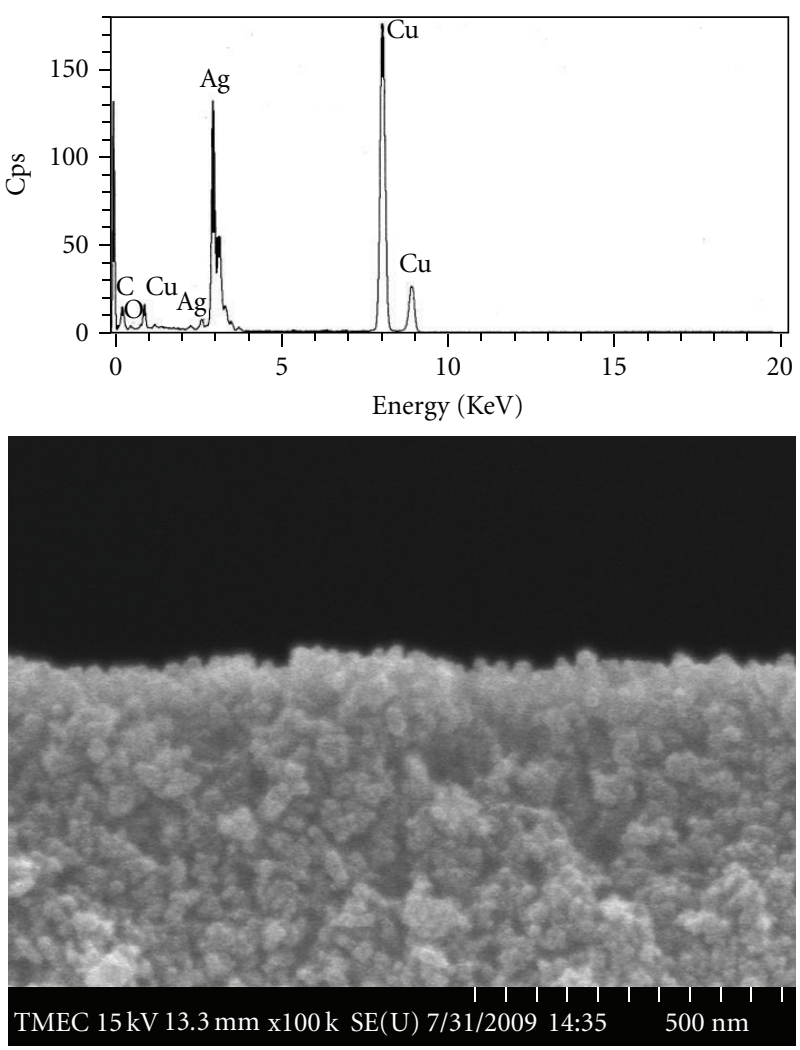

Figure 2: An SEM cross-sectional micrograph of the $\mathrm{TiO}_{2} / \mathrm{Ag}$ composite film with a UV exposure for 120 minutes. Inset shows an EDX spectrum indicating the presence of the Ag nanoparticles on the $\mathrm{TiO}_{2}$ films.

FTO glass with $0.5 \times 1.2 \mathrm{~cm}^{2} \mathrm{TiO}_{2}$ films was immersed in the $0.1 \mathrm{M} \mathrm{AgNO}_{3}$ solution for five seconds, then rinsed with DI water and dried in a $\mathrm{N}_{2}$ stream. The films were then exposed to a UV irradiation at $\lambda=254 \mathrm{~nm}$ using a Spectroline CM-10 Fluorescence Analysis Cabinet at an intensity of $\sim 0.31 \mathrm{~mW} / \mathrm{cm}^{2}$. We designed the experiment to vary exposure times for $5,10,15,20,30,60,90,120,150,180$, and 240 minutes for the photocatalytic reduction of $\mathrm{Ag}^{+}$to the metallic Ag nanoparticles. Finally, the $\mathrm{TiO}_{2} / \mathrm{Ag}$ electrodes were immersed in dye solution for 24 hours and prepared for dye-sensitized solar cells.

2.3. The Preparation of Pt Counter Electrodes. The counter electrodes were prepared by screen printing a thin layer of platinum $(\mathrm{Pt})$ with a size of $0.5 \times 1.2 \mathrm{~cm}^{2}$ using a platinum paste (Dyesol), on an FTO glass substrate $\left(2 \times 3 \mathrm{~cm}^{2}\right)$, and then sintered at $450^{\circ} \mathrm{C}$ for 30 minutes.

2.4. DSC Fabrication. A sandwich-type cell [26] was fabricated by assembling a sensitized $\mathrm{TiO}_{2}$ electrode using surlynbased polymer sheet ( $80 \mu \mathrm{m}$ thick) and sealed by a hot gun for a few seconds. The liquid electrolyte contained $0.5 \mathrm{M} \mathrm{LiI}$, $0.05 \mathrm{M} \mathrm{I}_{2}$, and $0.5 \mathrm{M}$ 4-tert-butyl pyridine in $90: 10 \mathrm{v} / \mathrm{v}$ of acetonitrile: 3 methyl-2-oxazolidinone. Electrolyte-injecting holes, made on the counter-electrode side, were sealed with surlyn and glass cover. 


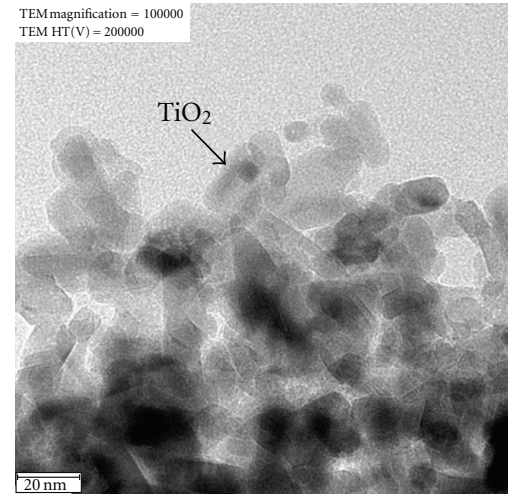

(a)

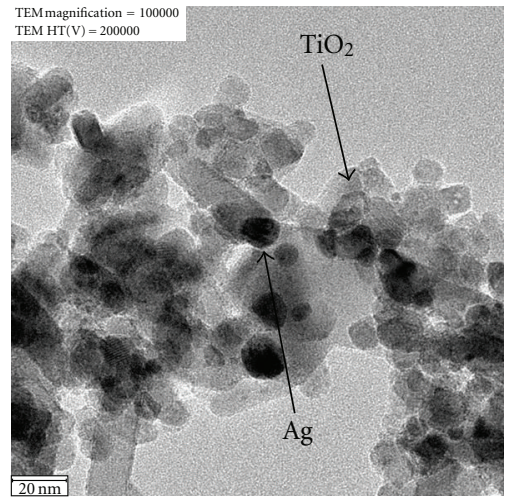

(b)

FIgURE 3: TEM micrographs of the $\mathrm{TiO}_{2}$ nanotubes (a) before and (b) after immersion in the $\mathrm{AgNO}_{3}$ solution with UV exposure for 120 minutes.

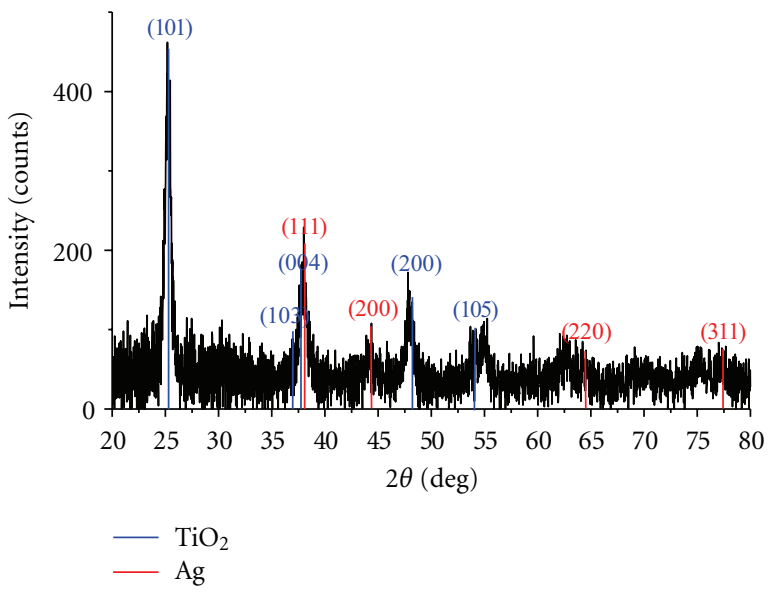

FIGURE 4: XRD peaks of the $\mathrm{TiO}_{2} / \mathrm{Ag}$ composite film with UV exposure for 120 minutes on an FTO glass substrate. (Note: graph plotted by OriginLab software program.)

2.5. Measurements. Optical absorption spectra of the film electrode samples were measured using a UV-visible spectrophotometer (Jasco model:V-530). In order to observe the microstructure and elemental analysis of the obtained $\mathrm{Ag}$ nanoparticles, the $\mathrm{Ag}$ nanoparticles were prepared on carbon-coated copper grids for observations by transmission electron microscopy (TEM JEOL model JSM-2010). The Xray diffraction (XRD JEOL-300) patterns were obtained by analyzing the $\mathrm{Ag} / \mathrm{TiO}_{2}$ films on the glass substrates. Scanning electron microscope (SEM JEOL model: JSM$6301 \mathrm{~F}$ ) was employed to record cross-sectional micrographs of the $\mathrm{Ag} / \mathrm{TiO}_{2}$ films. $J-V$ measurements were performed under a $450 \mathrm{~W}$ xenon light source which is able to provide $1000 \mathrm{~W} \cdot \mathrm{m}^{-2}$ sunlight equivalent irradiation (AM 1.5), using Keithley digital source meter (Model 2400) under the illuminated condition.

\section{Results and Discussion}

3.1. Morphology of the $\mathrm{TiO}_{2} / \mathrm{Ag}$ Deposited Films. The $\mathrm{TiO}_{2}$ films were prepared by screen printing 3 layers of the $\mathrm{TiO}_{2}$ paste and calcination at $450^{\circ} \mathrm{C}$ for 30 minutes. A thickness measured using SEM is approximately $13.8 \mu \mathrm{m}$ as shown in Figure 1 (in agreement with [27-30]).

The $\mathrm{TiO}_{2}$ films were loaded with the Ag nanoparticles using the $\mathrm{AgNO}_{3}$ soaking and the UV illumination treatment described in the experimental part 2.2. After the films were irradiated by the UV light, they turned brownish grey in a few minutes due to photocatalytic reduction of $\mathrm{Ag}^{+}$to $\mathrm{Ag}$ [31]. The Ag nanoparticles on the $\mathrm{TiO}_{2}$ particles were not readily observed by the SEM (Figure 2). However, The $\mathrm{TiO}_{2} / \mathrm{Ag}$ composite films were characterized using energy dispersive X-Ray spectroscopy (EDX) technique attached to the SEM. We found that the peaks of the Ag nanoparticles were present (Figure 2), suggesting the presence of the $\mathrm{Ag}$ nanoparticles on surface of the $\mathrm{TiO}_{2}$ films.

Figure 3(a) shows a TEM micrograph of the $\mathrm{TiO}_{2}$ nanoparticles from the $\mathrm{TiO}_{2}$ films before immersion in the $\mathrm{AgNO}_{3}$ solution. We found that the $\mathrm{TiO}_{2}$ nanoparticles were nanorods and the lengths were approximately $25 \mathrm{~nm}$. Figure 3(b) shows an example of the TEM images of the $\mathrm{TiO}_{2}$ nanorods from the films after immersion in the $\mathrm{AgNO}_{3}$ solution and exposed to the UV irradiation for 120 minutes. The result shows the presence of the $\mathrm{TiO}_{2}$ nanorods and the spherical Ag nanoparticles adsorbed on surfaces of the $\mathrm{TiO}_{2}$ nanorods. An example of XRD pattern of the $\mathrm{TiO}_{2} / \mathrm{Ag}$ composite films (Figure 4) shows that four $2 \theta$ diffraction peaks at $38.12,44.30,64.44$, and 77.40 could, respectively, be indexed as (111), (200), (220), and (311) planes of facecentered cubic Ag. Peaks at 25.36, 37.05, 37.90, 48.15, and 54.05 are indexed as (101), (103), (004), (200), and (105) planes of the anatase $\mathrm{TiO}_{2}$.

The Ag nanoparticles were also prepared on the carboncoated copper grids and exposed to varied UV exposure times of $0,5,10,15,20,30,60,90,120,150,180$ and 240 minutes. The average diameters of the Ag nanoparticles measured from the TEM micrographs using Image-Pro Plus 5.0 software program were approximately $4.36 \pm 2.53,4.56 \pm$ $1.78,5.39 \pm 1.83,6.20 \pm 1.65,7.17 \pm 2.59,10.98 \pm 1.80,15.57 \pm$ $3.26,19.16 \pm 3.71,23.55 \pm 4.26,27.51 \pm 8.05$, and $38.56 \pm 5.30$, respectively. The sizes of $\mathrm{Ag}$ nanoparticles were found to depend strongly on the UV exposure time (Figure 5) due to 

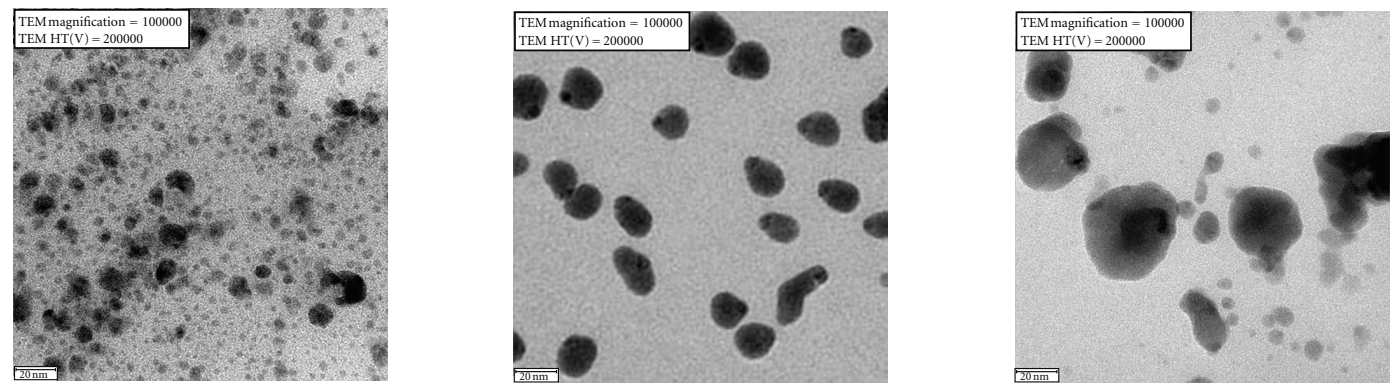

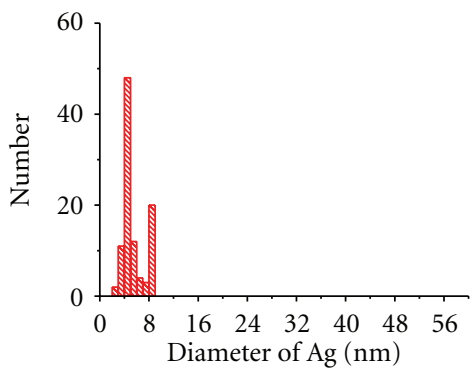

(a)

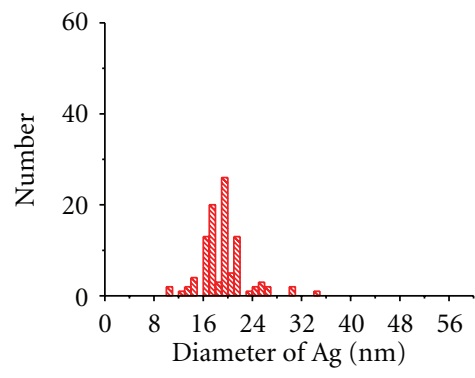

(b)

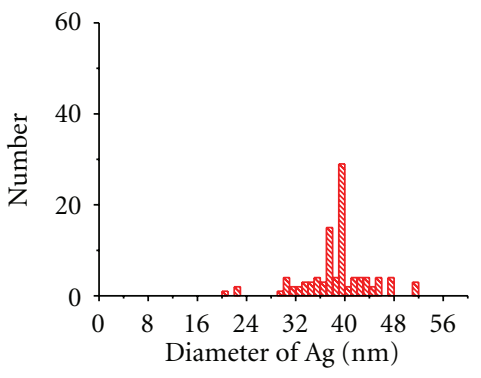

(c)

FIGURE 5: TEM micrographs and size distributions of silver nanoparticles prepared by photocatalytic reduction in a $0.1 \mathrm{M} \mathrm{AgNO}_{3}$ solution on the carbon-coated copper grids at UV exposure times of (a) 5 minutes, (b) 120 minutes, and (c) 240 minutes, respectively. The average size increases and the distribution broadens with an increase in the UV exposure time. (Note: graph plotted by OriginLab software program).
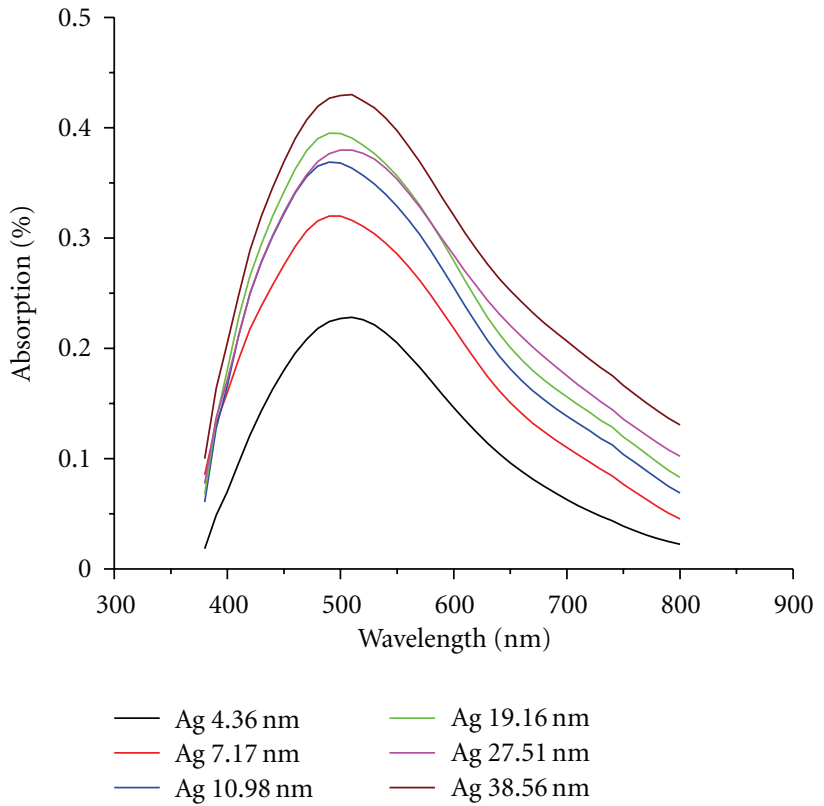

(a)

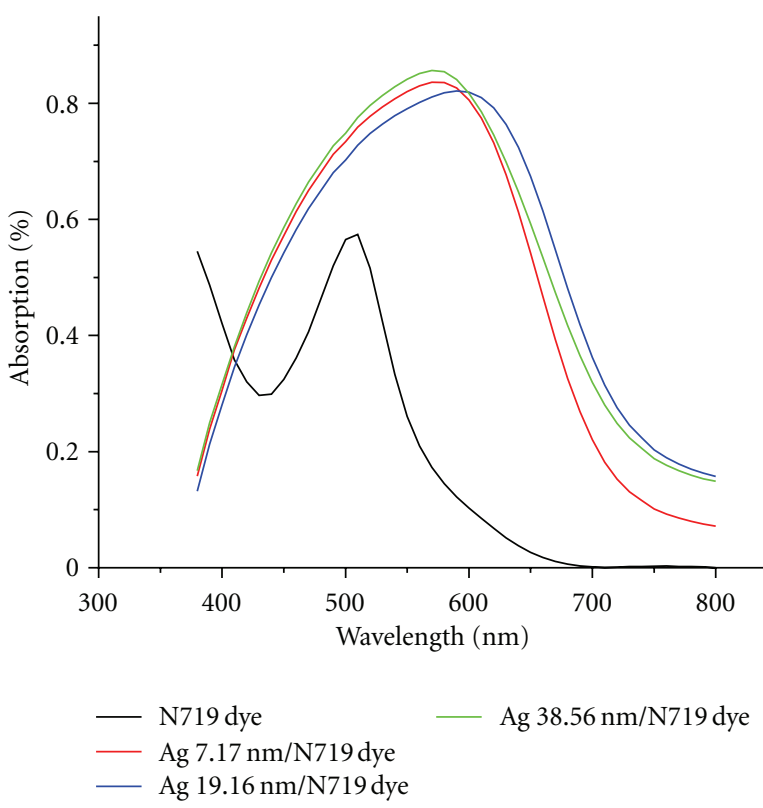

(b)

Figure 6: Optical absorption spectra of: (a) the Ag nanoparticle films with various particle sizes of the Ag nanoparticles in the range of 4.36-38.56 nm and (b) the Ag/N719 dye film compared with an optical absorption spectrum of $3 \times 10^{-5} \mathrm{M}$ N719 dye solution.

the photocatalytic reduction of the $\mathrm{Ag}^{+}$to the $\mathrm{Ag}$ metal in the form of the Ag nanoparticles where electrons were provided by water $[17,31]$.

\subsection{The Effect of the Ag Nanoparticle Size on Optical Absorp-} tion Spectra. The absorption spectrum of the Ag nanoparticles exhibits the surface plasmon peak at approximately $400 \mathrm{~nm}$ on the broad band [32]. Optical absorption spectra can be theoretically calculated using Mie's theory. When the particles having diameter $(R)$ are suspended in a medium with the dielectric constant $\left(\varepsilon_{m}\right)$, the dipolar absorption efficiency $\left(Q_{\text {abs }}\right)$ is given by

$$
Q_{\mathrm{abs}}=\frac{24 \pi R}{\lambda} \cdot \frac{\varepsilon_{m}^{3 / 2} \varepsilon^{\prime \prime}(\omega)}{\mathcal{\varepsilon}^{\prime \prime}(\omega)^{2}+\left\langle\varepsilon^{\prime}(\omega)+2 \varepsilon_{m}+48 \pi^{2} R^{2} \varepsilon_{m}^{2} / 5 \lambda^{2}\right\rangle^{2}},
$$




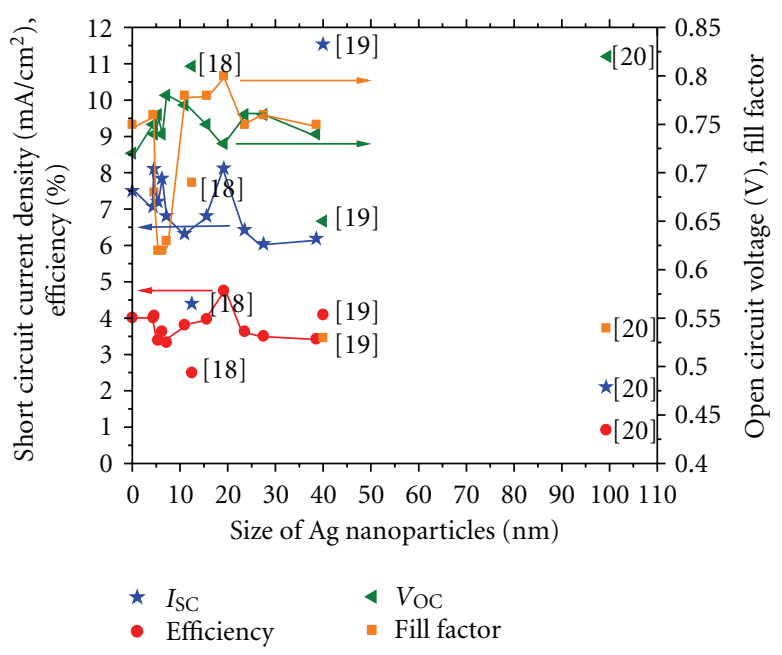

Figure 7: Open circuit voltages $\left(V_{\mathrm{OC}}\right)$, short circuit current densities $\left(J_{\mathrm{SC}}\right)$, fill factors $(\mathrm{FF})$, and efficiencies of the DSCs with varied sizes of the Ag nanoparticles compared with reported DSCs [18-20]. At [18], use $2 \mu \mathrm{m}$ of $\mathrm{TiO}_{2}$ thickness and size of $0.25 \mathrm{~cm}^{2}$, [19] use $15 \mu \mathrm{m}$ of $\mathrm{TiO}_{2}$ thickness and size of $0.25 \mathrm{~cm}^{2}$, [20] use $8.1 \mu \mathrm{m}$ of $\mathrm{TiO}_{2}$ thickness and size of $4.0 \mathrm{~cm}^{2}$, and this study uses $13.8 \mu \mathrm{m}$ of $\mathrm{TiO}_{2}$ thickness and size of $0.6 \mathrm{~cm}^{2}$.
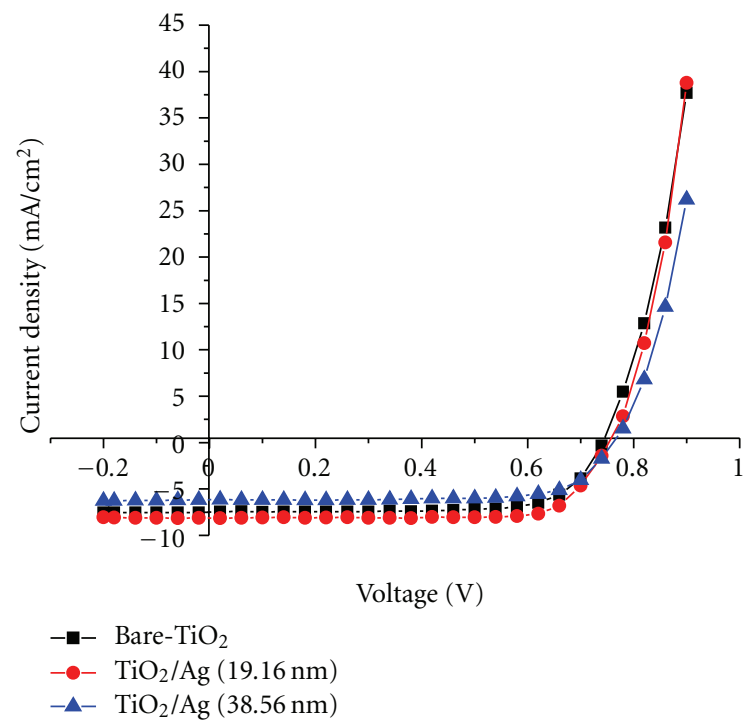

FIgURE 8: $J-V$ characteristics of the DSCs composed of the $\mathrm{TiO}_{2}$ electrodes with N719 dye before and after improvement with the Ag nanoparticles.

where $\lambda$ is a wavelength of the incoming light in the medium, and $\varepsilon^{\prime}(\omega)$ and $\varepsilon^{\prime \prime}(\omega)$ represent the real and imaginary parts of the dielectric function, $\varepsilon(\omega)$, respectively, $\left[\varepsilon(\omega)=\varepsilon^{\prime}(\omega)+\right.$ $\left.\varepsilon^{\prime \prime}(\omega)\right]$. Thus, the absorption efficiency of particles is a function of the dielectric constant of the metal, that of medium and the size of the particle.

From (1), the Mie's theory only successfully explains the absorption band for metallic nanoparticles in visible range, and,for radius less than $5 \mathrm{~nm}$, the width of the surface plasmon peak increases linearly with the reciprocal of the radius $[32,33]$. On the other hand, the width of the surface plasmon peak increases with an increase in the radius in the range larger than $10 \mathrm{~nm}$, because of inhomogeneous polarization of the particles in the electromagnetic field of the incoming light due to excitation of a different multiple modes which makes a peak in the spectrum at a different energy $[32,34]$. Figure $6(a)$ shows optical absorption spectra of the Ag nanoparticles films indicating an increase in wavelength (red shifted) with an increase in the diameters of the Ag nanoparticles because the width of the surface plasmon peak increases.

Figure 6(b) shows the absorption peak of the Ag/N719 dye film, it is found that the $\mathrm{Ag} 19.16 \mathrm{~nm} / \mathrm{N} 719$ dye film has a maximum peak width or red shift due to the surface plasmon resonance of the silver particles contributing to the absorption coefficient of the dye. The absorption of the Rudye can occur via the metal-ligand charge-transfer transition (MLCT), $t_{2} \rightarrow \pi^{*}$ MLCT transitions in the absorption maximum at 396 and $534 \mathrm{~nm}$, and $\pi \rightarrow \pi^{*}$ intraligand transition in the UV [35]. Thus, both the surface Plasmon resonance absorption of $\mathrm{Ag}$ nanoparticles and the $\mathrm{Ru}$-dye absorption for MLCT transition contributed to the total absorption.

3.3. The Effect of the Ag Nanoparticle Size on Efficiency of the DSCs. Parameters extracted from $J-V$ characteristics, for example, Figure 8, of the $\mathrm{TiO}_{2} / \mathrm{Ag}$ composite film electrode DSCs are shown in Table 1. The Ag nanoparticles of the average size of $19.16 \mathrm{~nm}(3.59 \pm 0.50$ weight \% of $\mathrm{Ag}$ nanoparticles in the $\mathrm{TiO}_{2} / \mathrm{Ag}$ composite) were found to result in the maximum value of short circuit current density of $8.12 \mathrm{~mA} / \mathrm{cm}^{2}$.

As shown in Table 1, the pure $\mathrm{TiO}_{2}$ electrode (reference cell) results in the short circuit current density $\left(J_{S C}\right)$ of $7.50 \mathrm{~mA} / \mathrm{cm}^{2}$, open circuit voltages $\left(V_{\mathrm{OC}}\right)$ of $0.72 \mathrm{~V}$, fill factors (FF) of 0.75 , and efficiency of $4.02 \%$. For the $\mathrm{TiO}_{2} / \mathrm{Ag}$ electrodes, after improvement with intercalation of $\mathrm{Ag}$ nanoparticles of which size ranging from 4.36 to $38.56 \mathrm{~nm}$, we found that the dye-sensitized solar cell which was prepared from the $\mathrm{TiO}_{2} / \mathrm{Ag}(19.16 \mathrm{~nm})$ electrode had maximum values of the $J_{\mathrm{SC}}, \mathrm{FF}$, and efficiency of $8.12 \mathrm{~mA} / \mathrm{cm}^{2}, 0.80$ and $4.76 \%$, respectively, with $V_{\mathrm{OC}}$ of 0.73 . Compared with the reference cell, the $\mathrm{TiO}_{2} / \mathrm{Ag}(19.16 \mathrm{~nm})$ is found to improve $J_{\mathrm{SC}}, \mathrm{FF}$, and efficiency because of an optimum electromagnetic field introduced by the silver plasmon resonance that enhances the optical absorption of the dye $[2,3,36]$. The other possible reason is that the Ag nanoparticles have a catalytic effect that increases the reaction rate between the semiconductor, dye, and the redox electrolyte and/or the internal photoemission from the $\mathrm{Ag}$ nanoparticles increases the photocurrent $[1,3,36]$. However, the dye-sensitized solar cells which were prepared from the $\mathrm{TiO}_{2} / \mathrm{Ag}$ electrodes with the $\mathrm{Ag}$ nanoparticle sizes bigger than $19.16 \mathrm{~nm}$ have low values of the $J_{\mathrm{SC}}$. It is believed that with the Ag particle sizes bigger than $19.16 \mathrm{~nm}$, Schottky barriers formed at the $\mathrm{TiO}_{2} / \mathrm{Ag}$ contacts become dominant and retard electron transport in the conduction bands $[1,3,37,38]$.

Figure 7 plots $J_{\mathrm{SC}}, V_{\mathrm{OC}}, \mathrm{FF}$, and efficiencies versus the sizes of the Ag nanoparticles. The DSCs in our study were 


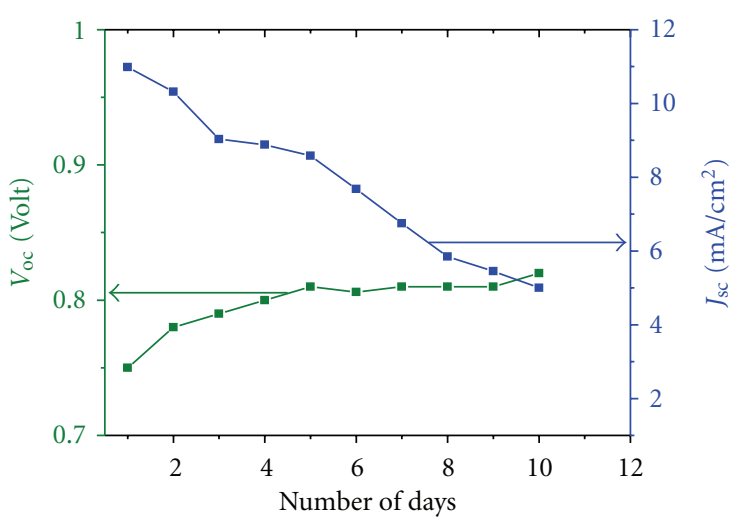

(a)

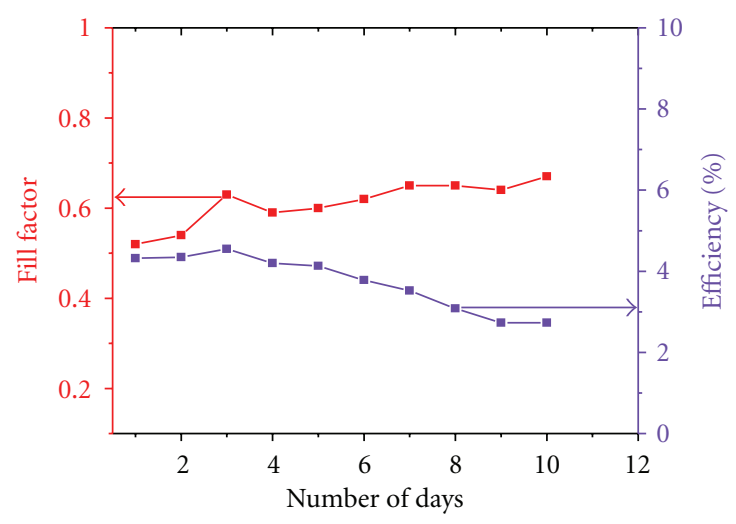

(b)

FIgURE 9: Variation of (a) open-circuit voltage $\left(V_{\mathrm{OC}}\right)$ and short-circuit current density $\left(J_{\mathrm{SC}}\right)$, (b) fill factor $(\mathrm{FF})$ and energy conversion efficiency of DSC with $\mathrm{TiO}_{2} / \mathrm{Ag}(19.16 \mathrm{~nm})$ electrode during a short-term stability test.

TABLE 1: Weight (\%) of Ag nanoparticles obtained from SEM-EDX analysis, short circuit current densities ( $J_{\text {SC }}$ ), open circuit voltages $\left(V_{\mathrm{OC}}\right)$, fill factors $(\mathrm{FF})$, and efficiencies of DSCs prepared using the $\mathrm{TiO}_{2} / \mathrm{Ag}$ composite film electrodes compared with pure TiO 2 electrode (reference) under AM1.5.

\begin{tabular}{|c|c|c|c|c|c|c|}
\hline No. & $\begin{array}{c}\text { Size of } \mathrm{Ag} \\
\text { nanoparticles on } \mathrm{TiO}_{2} \\
\text { electrode }(\mathrm{nm})\end{array}$ & Weight (\%) of Ag nanoparticles & $J_{\mathrm{SC}}\left(\mathrm{mA} / \mathrm{cm}^{2}\right)$ & $V_{\mathrm{OC}}(V)$ & $\mathrm{FF}$ & Efficiency (\%) \\
\hline 1 & pure $\mathrm{TiO}_{2}$ (reference) & 0 & 7.50 & 0.72 & 0.75 & 4.02 \\
\hline 2 & $4.36 \pm 2.53$ & $3.30 \pm 0.35$ & 7.07 & 0.75 & 0.76 & 4.02 \\
\hline 3 & $4.56 \pm 1.78$ & $4.01 \pm 0.56$ & 8.11 & 0.74 & 0.68 & 4.07 \\
\hline 4 & $5.39 \pm 1.83$ & $3.52 \pm 0.27$ & 7.21 & 0.76 & 0.62 & 3.40 \\
\hline 5 & $6.20 \pm 1.65$ & $3.45 \pm 0.30$ & 7.84 & 0.74 & 0.62 & 3.64 \\
\hline 6 & $7.17 \pm 2.59$ & $3.56 \pm 0.30$ & 6.81 & 0.78 & 0.63 & 3.34 \\
\hline 7 & $10.98 \pm 1.80$ & $3.54 \pm 0.38$ & 6.32 & 0.77 & 0.78 & 3.82 \\
\hline 8 & $12.5[18]$ & - & 4.40 & 0.81 & 0.69 & 2.5 \\
\hline 9 & $15.57 \pm 3.26$ & $3.29 \pm 0.11$ & 6.81 & 0.75 & 0.78 & 3.98 \\
\hline 10 & $19.16 \pm 3.71$ & $3.59 \pm 0.50$ & 8.12 & 0.73 & 0.80 & 4.76 \\
\hline 11 & $23.55 \pm 4.26$ & $4.14 \pm 0.94$ & 6.43 & 0.76 & 0.75 & 3.64 \\
\hline 12 & $27.51 \pm 8.05$ & $4.20 \pm 0.34$ & 6.04 & 0.76 & 0.76 & 3.51 \\
\hline 13 & $38.56 \pm 5.30$ & $4.42 \pm 0.45$ & 6.19 & 0.74 & 0.75 & 3.43 \\
\hline 14 & 40 [19] & - & 11.53 & 0.65 & 0.53 & 4.10 \\
\hline 15 & $\sim 100[20]$ & - & 2.10 & 0.82 & 0.54 & 0.93 \\
\hline
\end{tabular}

compared with the Ag nanoparticle size of around 12.5 [18], $40[19]$, and 100 [20] nm on the $\mathrm{TiO}_{2}$ electrodes reported elsewhere. Due to different thicknesses of the $\mathrm{TiO}_{2}$ layers prepared, direct comparison cannot be made. However, the improved $J_{\mathrm{SC}}$ of the best DSC prepared in this study is noteworthy. Compared with the reported DSCs with the $\mathrm{Ag}$ nanowires of $40 \mathrm{~nm}$ in diameter and $20 \mu \mathrm{m}$ in length [19] with the $J_{\mathrm{SC}}$ of $11.53 \mathrm{~mA} / \mathrm{cm}^{2}$, the best DSC in this study has a lower value of $J_{\mathrm{SC}}$. The high value of $J_{\mathrm{SC}}$ in the Ag nanowire DSCs has been reported to be due to metal network formation by adding Ag nanowires to improve the production and transportation of photon-generated current [39].

However the $V_{\mathrm{OC}}, \mathrm{FF}$, and efficiency values of the Ag nanowire DSCs are not higher than the best value reported in this study. When compared with the reported DSCs with the Ag nanoparticle size of around $100 \mathrm{~nm}$ [20], the values of $J_{\mathrm{SC}}, V_{\mathrm{OC}}, \mathrm{FF}$ and Efficiency follow a decreasing trend after the maximum values because the Schottky barriers formed at the $\mathrm{TiO}_{2} / \mathrm{Ag}$ contact retarding electron transport in conduction bands $[1,3]$. Therefore, the Ag nanoparticles size of $19.16 \mathrm{~nm}$ prepared in this study is an appropriate size to improve $J_{\mathrm{SC}}$ of the DSCs.

Figure 8 shows the $J-V$ characteristics of the DSCs before and after improvement by the intercalation of the $\mathrm{Ag}$ nanoparticles into the $\mathrm{TiO}_{2}$ electrodes. The optimum size of the $\mathrm{Ag}$ nanoparticle of $19.16 \mathrm{~nm}$ was found to give the maximum $J_{\mathrm{SC}}$ and the maximum efficiency of the DSCs. The intercalation of the $\mathrm{Ag}$ nanoparticles to the $\mathrm{TiO}_{2}$ layer has been shown not to significantly affect values of $V_{\mathrm{OC}}$, Figure 7 , 
because the $V_{\mathrm{OC}}$ is determined by the redox potential and the Fermi energy of semiconductors $[1,36]$, which do not change significantly with the change in size of the Ag nanoparticles.

Figure 9 shows the short-term stability of the dyesensitized solar cells which were kept in an ambient atmosphere. The $J-V$ characteristics of dye-sensitized solar cell using the $\mathrm{Ag}$ nanoparticle size of $19.16 \mathrm{~nm}$ on the $\mathrm{TiO}_{2}$ electrode were measured at $24 \mathrm{~h}$ interval. It was found that the efficiency of the dye-sensitized solar cells was slightly enhanced in the first 3 days because of the increases in $V_{\mathrm{OC}}$ and FF increase. However, from the 4th day, the efficiency of dyesensitized of solar cells began to decrease because of the decrease in short circuit current density. This could be due to the instability of the Ag nanoparticles in the $\mathrm{I}^{-} / \mathrm{I}_{3}{ }^{-}$redox electrolyte [1].

\section{Conclusion}

The DSCs composed of mesoporous $\mathrm{TiO}_{2}$ films, N719 Ru dye and the redox of $\mathrm{I}^{-} / \mathrm{I}_{3}{ }^{-}$were prepared and improved by the intercalation of the $\mathrm{Ag}$ nanoparticles into the $\mathrm{TiO}_{2}$ electrodes by photoreduction method. The Ag nanoparticles were face centered cubic and varied in size in the range of 4.36$38.65 \mathrm{~nm}$. The $\mathrm{TiO}_{2} / \mathrm{Ag}$ composite films were characterized by XRD, SEM, TEM and UV-Vis Spectrophotometer. The optimum size of the Ag nanoparticles was $19.16 \mathrm{~nm}$ giving the maximum $J_{\mathrm{SC}}$ and efficiency of $8.12 \mathrm{~mA} / \mathrm{cm}^{2}$ and $4.76 \%$, respectively.

\section{Acknowledgments}

The authors thank the National Metal and Materials Technology Center (MTEC) and Institute of Solar Energy Technology Development (SOLARTEC), Thailand for financial support.

\section{References}

[1] C. Wen, K. Ishikawa, M. Kishima, and K. Yamada, "Effects of silver particles on the photovoltaic properties of dye-sensitized $\mathrm{TiO}_{2}$ thin films," Solar Energy Materials and Solar Cells, vol. 61, no. 4, pp. 339-351, 2000.

[2] K. C. Lee, SU. J. Lin, C. H. Lin, C. S. Tsai, and YU. J. Lu, "Size effect of Ag nanoparticles on surface plasmon resonance," Surface and Coatings Technology, vol. 202, no. 22-23, pp. 53395342, 2008.

[3] G. Zhao, H. Kozuka, and T. Yoko, "Effects of the incorporation of silver and gold nanoparticles on the photoanodic properties of rose bengal sensitized $\mathrm{TiO}_{2}$ film electrodes prepared by solgel method," Solar Energy Materials and Solar Cells, vol. 46, no. 3, pp. 219-231, 1997.

[4] A. M. Glass, P. F. Lioa, J. G. Bergman, and D. H. Olson, "Interaction of metal particles with adsorbed dye molecules: absorption and luminescence," Optics Letters, vol. 5, pp. 3683707, 1980.

[5] Z. Y. Zhu, C. Mao, R. Y. Yang, L. X. Dai, and C. S. Nie, "Surfaceenhanced Raman scattering of $\mathrm{Ru}(\mathrm{II})$ homo- and heterolytic complexes with $2,2^{\prime}$-bipyridine and 1,1' -biisoquinoline in aqueous silver sol," Journal of Raman Specroscopy, vol. 24, pp. 221-226, 1993.
[6] W. J. Yoon, K. Y. Jung, J. Liu et al., "Plasmon-enhanced optical absorption and photocurrent in organic bulk heterojunction photovoltaic devices using self-assembled layer of silver nanoparticles," Solar Energy Materials and Solar Cells, vol. 94, no. 2, pp. 128-132, 2010.

[7] D. M. Schaadt, B. Feng, and E. T. Yu, "Enhanced semiconductor optical absorption via surface plasmon excitation in metal nanoparticles," Applied Physics Letters, vol. 86, no. 6, Article ID 063106, pp. 1-3, 2005.

[8] C. F. Eagen, "Nature of the enhanced optical absorption of dye-coated Ag island films," Applied Optics, vol. 20, no. 17, pp. 3035-3042, 1981.

[9] J. J. Mock, M. Barbic, D. R. Smith, D. A. Schultz, and S. Schultz, "Shape effects in plasmon resonance of individual colloidal silver nanoparticles," Journal of Chemical Physics, vol. 116, no. 15, pp. 6755-6759, 2002.

[10] P. Royer, J. P. Goudonnet, R. J. Warmack, and T. L. Ferrell, "Substrate effects on surface-plasmon spectra in metal-island films," Physical Review B, vol. 35, no. 8, pp. 3753-3759, 1987.

[11] G. Xu, M. Tazawa, P. Jin, S. Nakao, and K. Yoshimura, "Wavelength tuning of surface plasmon resonance using dielectric layers on silver island films," Applied Physics Letters, vol. 82, no. 22, pp. 3811-3813, 2003.

[12] M. Ihara, K. Tanaka, K. Sakaki, I. Honma, and K. Yamada, "Enhancement of the absorption coefficient of cis-(NCS)2 bis(2,2'-bipyridyl-4,4'-dicarboxylate)rutheniuin(II) dye in dye-sensitized solar cells by a silver island film," Journal of Physical Chemistry B, vol. 101, no. 26, pp. 5153-5157, 1997.

[13] J. Okumu, C. Dahmen, A. N. Sprafke, M. Luysberg, G. von Plessen, and M. Wuttig, "Photochromic silver nanoparticles fabricated by sputter deposition," Journal of Applied Physics, vol. 97, no. 9, Article ID 094305, pp. 1-6, 2005.

[14] G. Sandmann, H. Dietz, and W. Plieth, "Preparation of silver nanoparticles on ITO surfaces by a double-pulse method," Journal of Electroanalytical Chemistry, vol. 491, no. 1-2, pp. 7886,2000 .

[15] L. Miao, Y. Ina, S. Tanemura et al., "Fabrication and photochromic study of titanate nanotubes loaded with silver nanoparticles," Surface Science, vol. 601, no. 13, pp. 27922799, 2007.

[16] C. He, YA. Xiong, J. Chen, C. Zha, and X. Zhu, "Photoelectrochemical performance of $\mathrm{Ag}-\mathrm{TiO}_{2} / \mathrm{ITO}$ film and photoelectrocatalytic activity towards the oxidation of organic pollutants," Journal of Photochemistry and Photobiology A: Chemistry, vol. 157, no. 1, pp. 71-79, 2003.

[17] H. Hidaka, H. Honjo, S. Horikoshi, and N. Serpone, "Photoinduced $\mathrm{Ag}_{n}^{0}$ cluster deposition. Photoreduction of $\mathrm{Ag}^{+}$ions on a $\mathrm{TiO}_{2}$-coated quartz crystal microbalance monitored in real time," Sensors and Actuators, B, vol. 123, no. 2, pp. 822-828, 2007.

[18] M. Ihara, M. Kanno, and S. Inoue, "Photoabsorptionenhanced dye-sensitized solar cell by using localized surface plasmon of silver nanoparticles modified with polymer," Physica E, vol. 42, pp. 2867-2871, 2010.

[19] T. Y. Chen, C. M. Fan, J. Y. Wu, and T. L. Lin, "Hybrid silver nanowire/titanium oxides nanocomposites as anode for dye-sensitized solar cell application," Journal of the Chinese Chemical Society, vol. 56, no. 6, pp. 1244-1249, 2009.

[20] C. S. Chou, R. U. Y. Yang, C. K. Yeh, and Y. J. Lin, "Preparation of $\mathrm{TiO}_{2} / \mathrm{Nano}$-metal composite particles and their applications in dye-sensitized solar cells," Powder Technology, vol. 194, no. 1-2, pp. 95-105, 2009.

[21] I. Paramasivam, J. M. Macak, A. Ghicov, and P. Schmuki, "Enhanced photochromism of Ag loaded self-organized $\mathrm{TiO}_{2}$ 
nanotube layers," Chemical Physics Letters, vol. 445, no. 4-6, pp. 233-237, 2007.

[22] Y. Liu, X. Wang, F. Yang, and X. Yang, "Excellent antimicrobial properties of mesoporous anatase $\mathrm{TiO}_{2}$ and $\mathrm{Ag} / \mathrm{TiO}{ }_{2}$ composite films," Microporous and Mesoporous Materials, vol. 114, no. 1-3, pp. 431-439, 2008.

[23] S. K. Lim, S. K. Lee, S. H. Hwang, and H. Kim, "Photocatalytic deposition of silver nanoparticles onto organic/inorganic composite nanofibers," Macromolecular Materials and Engineering, vol. 291, no. 10, pp. 1265-1270, 2006.

[24] K. Naoi, Y. Ohko, and T. Tatsuma, " $\mathrm{TiO}_{2}$ films loaded with silver nanoparticles: control of multicolor photochromic behavior," Journal of the American Chemical Society, vol. 126, no. 11, pp. 3664-3668, 2004.

[25] E. Ramasamy, W. J. Lee, D. Y. Lee, and J. S. Song, "Portable, parallel grid dye-sensitized solar cell module prepared by screen printing," Journal of Power Sources, vol. 165, no. 1, pp. 446-449, 2007.

[26] M. K. I. Senevirathna, P. K. D. D. P. Pitigala, E. V. A. Premalal, K. Tennakone, G. R. A. Kumara, and A. Konno, "Stability of the $\mathrm{SnO}_{2} / \mathrm{MgO}$ dye-sensitized photoelectrochemical solar cell," Solar Energy Materials and Solar Cells, vol. 91, no. 6, pp. 544-547, 2007.

[27] S. K. Deb, "Dye-sensitized $\mathrm{TiO}_{2}$ thin-film solar cell research at the national renewable energy laboratory (NREL)," Solar Energy Materials and Solar Cells, vol. 88, no. 1, pp. 1-10, 2005.

[28] J. Jiu, S. Isoda, M. Adachi, and F. Wang, "Preparation of $\mathrm{TiO}_{2}$ nanocrystalline with 3-5 nm and application for dyesensitized solar cell," Journal of Photochemistry and Photobiology A, vol. 189, no. 2-3, pp. 314-321, 2007.

[29] K. Onoda, S. Ngamsinlapasathian, T. Fujieda, and S. Yoshikawa, "The superiority of Ti plate as the substrate of dyesensitized solar cells," Solar Energy Materials and Solar Cells, vol. 91, no. 13, pp. 1176-1181, 2007.

[30] J. Kallioinen, M. R. Hassan, G. S. Paraoanu, and J. KorppiTommola, "Dye-sensitized nanostructured $\mathrm{TiO}_{2}$ film based photoconductor," Journal of Photochemistry and Photobiology A, vol. 195, no. 2-3, pp. 352-356, 2008.

[31] Y. Ohko, T. Tatsuma, T. Fujii et al., "Multicolour photochromism of $\mathrm{TiO}_{2}$ films loaded with silver nanoparticles," Nature Materials, vol. 2, no. 1, pp. 29-31, 2003.

[32] F. Mafuné, J. Y. Kohno, Y. Takeda, T. Kondow, and H. Sawabe, "Formation and size control of silver nanoparticles by laser ablation in aqueous solution," Journal of Physical Chemistry B, vol. 104, no. 39, pp. 9111-9117, 2000.

[33] D. K. Bhui, H. Bar, P. Sarkar, G. P. Sahoo, S. P. De, and A. Misra, "Synthesis and UV-vis spectroscopic study of silver nanoparticles in aqueous SDS solution," Journal of Molecular Liquids, vol. 145, no. 1, pp. 33-37, 2009.

[34] R. Das, S. S. Nath, D. Chakdar, G. Gope, and R. Bhattacharjee, "Preparation of silver nanoparticles and their characterization," Journal of Nanotechnology, vol. 5, pp. 1-6, 2009.

[35] D. S. Wang and M. Kerker, "Enhanced Raman scattering by molecules adsorbed at the surface of colloidal spheroids," Physical Review B, vol. 24, no. 4, pp. 1777-1790, 1981.

[36] K. Ishikawa, C. J. Wen, K. Yamada, and T. Okubo, "The photocurrent of dye-sensitized solar cells enhanced by the surface plasmon resonance," Journal of Chemical Engineering of Japan, vol. 37, no. 5, pp. 645-649, 2004.

[37] N. K. Swami, S. Srivastava, and H. M. Ghule, "The role of the interfacial layer in Schottky barrier solar cells," Journal of Physics D: Applied Physics, vol. 12, no. 5, article 18, pp. 765771, 1979.
[38] C. M. H. Klimpke and P. T. Landsberg, "An improved analysis of the Schottky barrier solar cell," Solid State Electronics, vol. 24, no. 5, pp. 401-406, 1981.

[39] A. V. Rupa, D. Manikandan, D. Divakar, and T. Sivakumar, "Effect of deposition of $\mathrm{Ag}$ on $\mathrm{TiO}_{2}$ nanoparticles on the photodegradation of Reactive Yellow-17," Journal of Hazardous Materials, vol. 147, no. 3, pp. 906-913, 2007. 


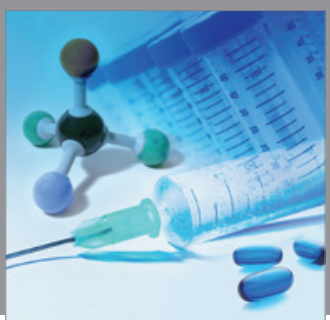

International Journal of

Medicinal Chemistry

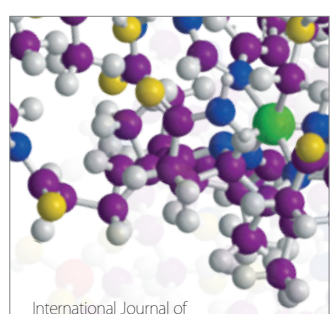

Carbohydrate Chemistry

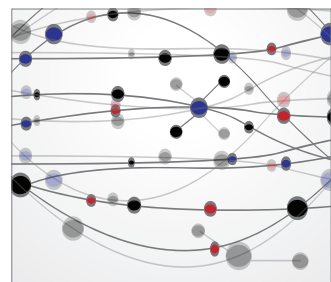

The Scientific World Journal
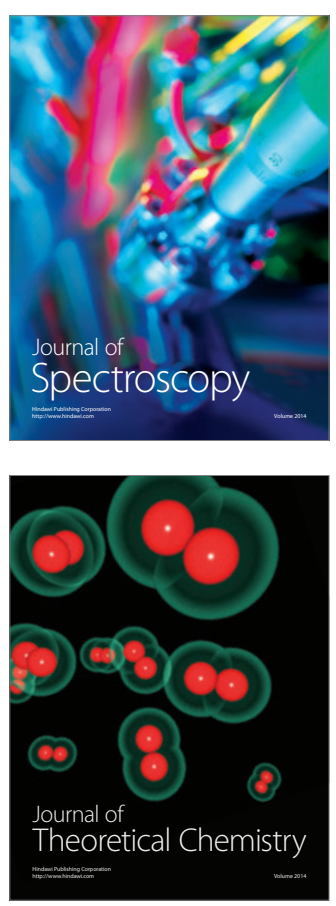
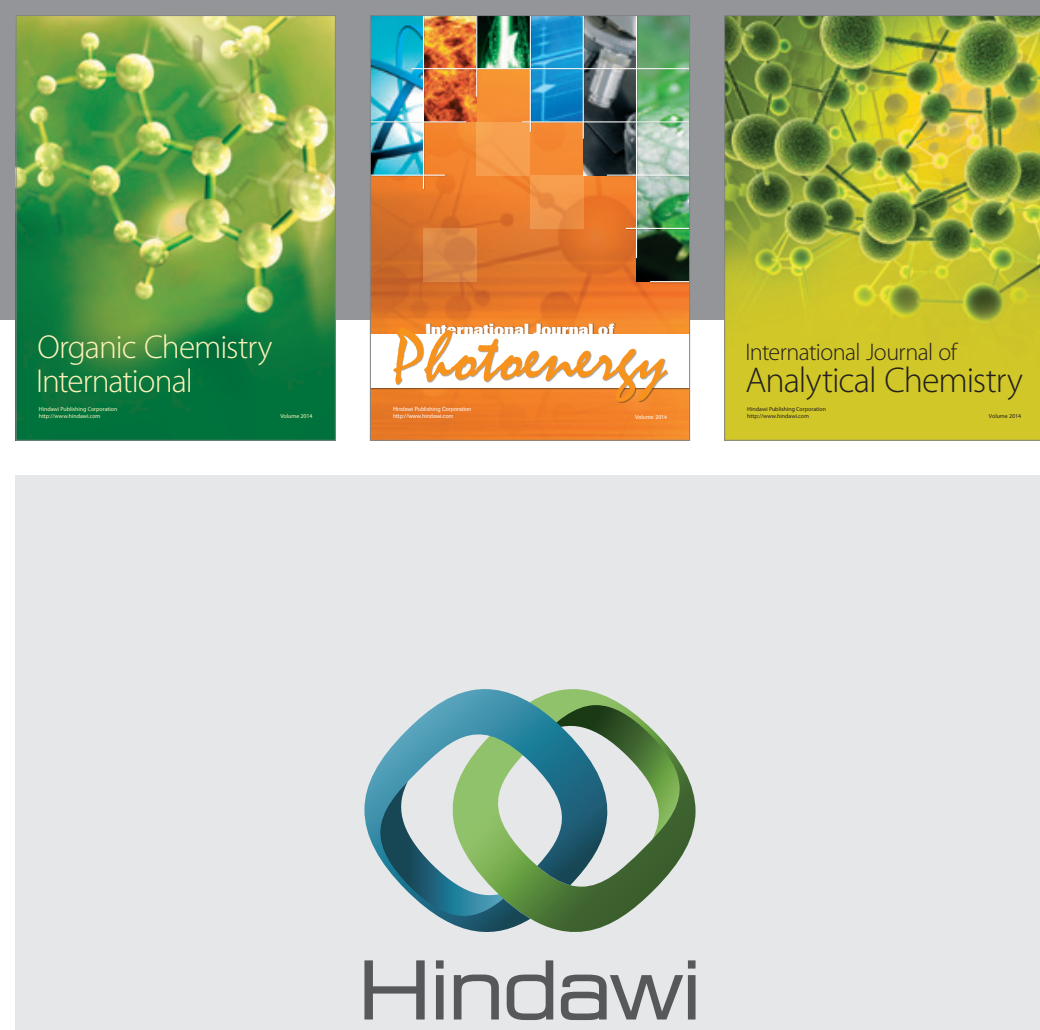

Submit your manuscripts at

http://www.hindawi.com
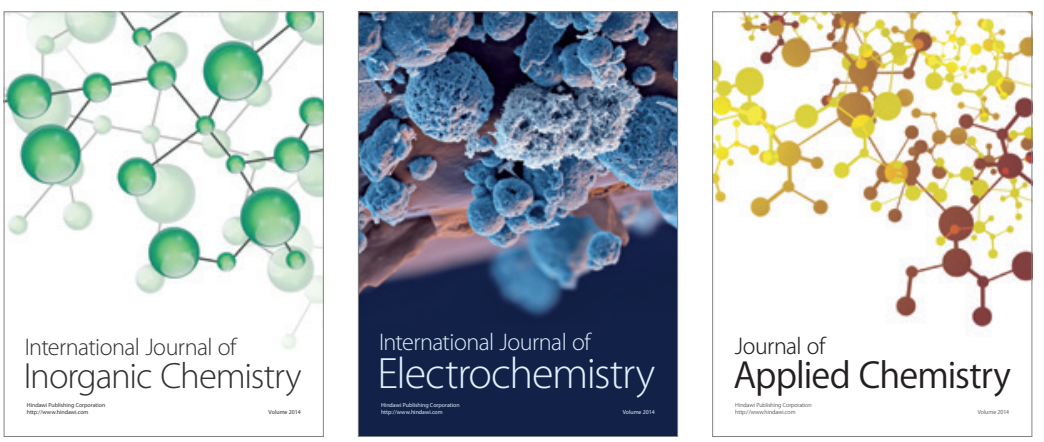

Journal of

Applied Chemistry
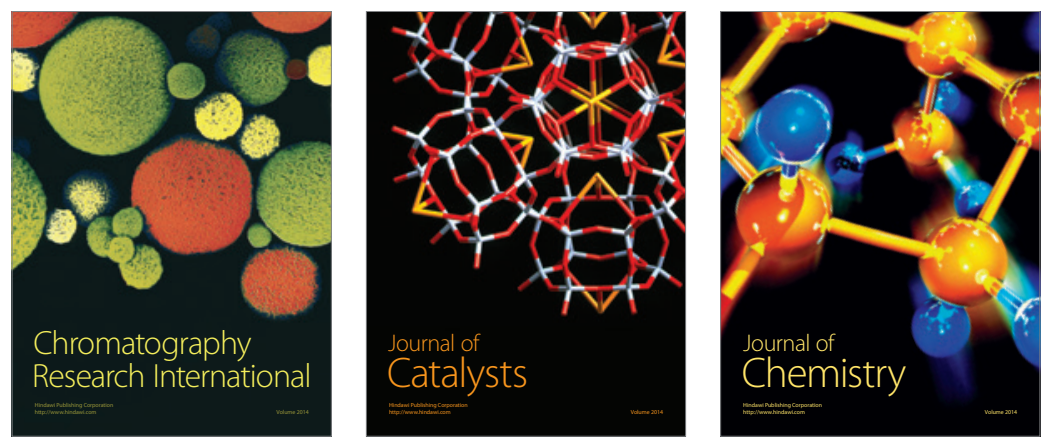
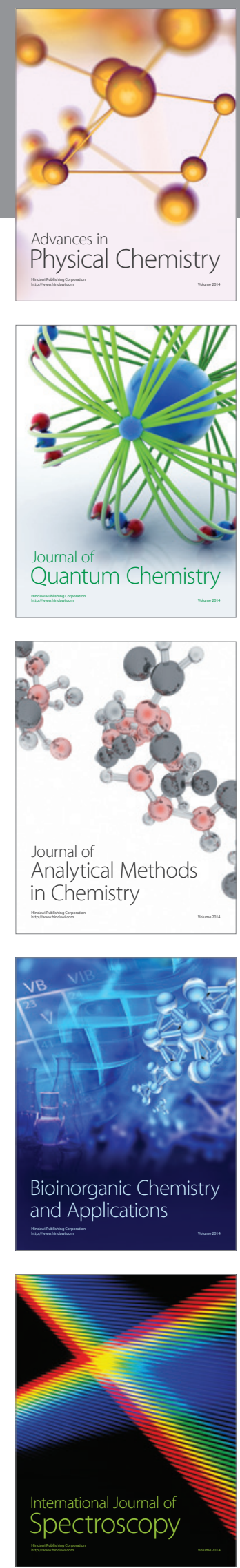